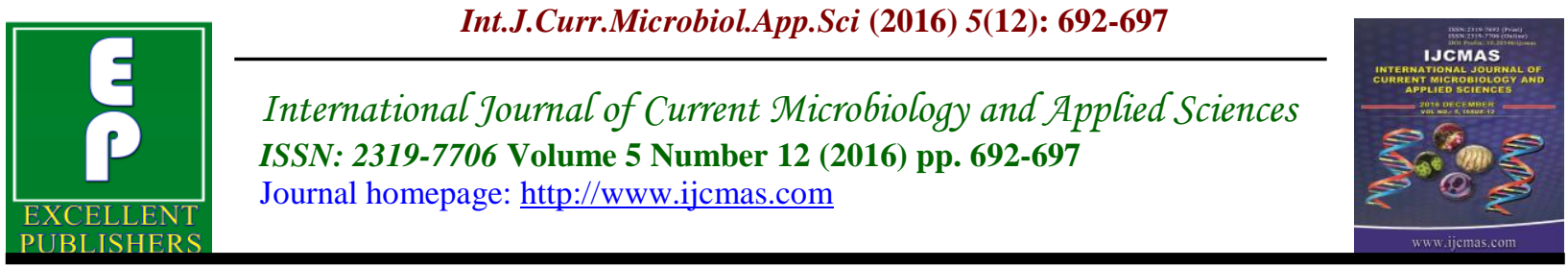

Original Research Article

http://dx.doi.org/10.20546/ijcmas.2016.512.078

\title{
Inhibitory Effect of Curcumin on Biofilm Produced by Bacterial Pathogens
}

\author{
M.V. Pravin Charles*, Arunava Kali, Bhuvaneshwar and K.S. Seetha \\ Department of Microbiology, Mahatma Gandhi Medical College and Research Institute, \\ Pillaiyarkuppam, Pondicherry - 607 402, India \\ *Corresponding author
}

Keywords

Biofilm, curcumin, Curcuma longa, antibacterial,

Bacterial Pathogens.

\begin{tabular}{l}
\hline Article Info \\
\hline Accepted: \\
26 November 2016 \\
Available Online: \\
10 December 2016
\end{tabular}

\section{A B S T R A C T}

Biofilm production in bacterial pathogens is a serious threat to medical management of infections. Owing to decreased penetration through biofilm matrix, most antibiotics fail to effectively eliminate these bacterial strains which continue to persist and result in emergence of drug resistance in healthcare setups. Therefore, a bioactive substance with biofilm inhibitory action is more likely to enhance the antimicrobial effect of antibiotic therapy. To investigate the antibiofilm action of curcumin in bacterial pathogens. Biofilm producing bacterial strains isolated from various samples were identified by Congo red agar method. These isolates were inoculated on Congo red agar with increasing concentrations of curcumin $(2,4,8,16,32,64,128,256$ and $512 \mu \mathrm{g} / \mathrm{ml})$ to detect the inhibition of biofilm formation at its various concentration. Biofilm production was detected among 60 isolates i.e. Escherichia coli $(\mathrm{n}=23,38.3 \%)$, Klebsiella pneumoniae $(\mathrm{n}=13,21.6 \%)$, Staphylococcus aureus $(\mathrm{n}=13,21.6 \%)$, Citrobacter freundii $(\mathrm{n}=6$, $10 \%)$, Pseudomonas aeruginosa $(\mathrm{n}=3,5 \%)$ and Enterococcus faecalis $(\mathrm{n}=2,3.3 \%)$ by Congo red agar. Majority (53.3\%) were from urine samples, followed by pus, sputum, aspirate and endotracheal secretion. These isolates showed minimum biofilm inhibitory concentration (MBIC) ranging from 4 to $128 \mu \mathrm{g} / \mathrm{ml}$. Among gram negative bacteria, higher MBIC was found among E. coli $(79.3 \%$ isolates with MBIC $128 \mu \mathrm{g} / \mathrm{ml}$ ) and among gram positive bacteria $84.6 \% \mathrm{~S}$. aureus isolates had MBIC of $32 \mu \mathrm{g} / \mathrm{ml}$. Curcumin was found to be a potent bioactive substance which inhibits biofilm formation in gram positive and gram negative bacterial clinical isolates. It may have promising role in treatment of infections with biofilm forming bacteria in combination therapy with antibiotics.

\section{Introduction}

Biofilm are complex microbial ecosystem which are adherent to a substratum or interface or to each otherin a self-produced extracellular polymeric matrix. Biofilm producers represent $85 \%$ of human related infections of which $65 \%$ are health care associated (Percival et al., 2015). Biofilm producing microorganisms are common among critically ill patients increasing the mortality. They also have reduced susceptibility to antimicrobial agents. The proposed mechanisms for such reduced susceptibility includes slower growth rate of these organisms which reduces the uptake of the antibiotics and delayed penetration of the same through the matrix (Donlan, 2002). 
Hence, antimicrobial resistance among the biofilm producing clinical bacterial strains make the treatment cumbersome (Reiter et al., 2011)The curcumoids are a group of phytochemicals produced by Curcuma longa which is a rhizome with common name turmeric (Ammon, 1991). These plants are foundfrequently in Indian subcontinent and South East Asia (Negi et al., 2014)mong the curcumoids produced by these plants curcumin or diferuloylmethane has antibacterial, antiviral, antifungal and antibiofilm effect. The curcumin content of these plants varies from plant species and their geographical location (Hayakawa et al., 2011). The safety of curcumin in high doses has provoked its utility in combination with various antimicrobial preparations. The aim of our study was to determine the antibiofilm action of curcumin.

\section{Materials and Methods}

A prospective study was conducted over a period of six months from May to October 2015 in department of Microbiology of our tertiary care teaching hospital in southern part of India. Our study had two arms one was 'the synergistic effect of curcumin with antibiotics against biofilm, was the subject of early publication (Kali et al., 2016). We present another arm of our study on the inhibitory effect of curcumin on the biofilm produced by microbes.

Bacterial strains isolated from various clinical samples were included in the study. Samples were collected with aseptic precautions and were processed as per standard laboratory procedures. The bacterial strains isolated from various clinical samples were subjected to biofilm detection and determination of minimum biofilm inhibitory concentration (MBIC) for curcumin.

Detection of biofilm production was carried out by Congo red agar method (Freeman et al., 1989). The bacterial isolates were inoculated on this medium.After incubation at $37^{\circ} \mathrm{C}$ for 48 hours the plates were observed for biofilm production. It was indicated by presence of dry black crystalline colonies. The strains which were non biofilm producers remained pink and had no crystalline texture.

We have used Congo red agar media with increasing concentration of curcumin (agar dilution) to determine the MBIC of curcumin among various bacterial strains.Under proper aseptic precautions curcumin powder was dissolved in dimethyl sulfoxide (DMSO) and a stock solution $(128 \mathrm{mg} / \mathrm{L})$ of curcumin was prepared. Required volumes of the stock solution of curcumin were added to molten brain heart infusion (BHI) agar(with 5\% sucrose and $0.08 \%$ Congo red) at $55^{\mathrm{O}} \mathrm{C}$ to achieve final curcumin test concentration of 2, 4, 8, 16, 32, 64, 128, 256 and $512 \mu \mathrm{g} / \mathrm{ml}$. All biofilm producer isolates were inoculated on Congo red agar plates with increasing concentration of curcumin. The inhibition of biofilm production was noted when an isolate which produced black crystalline colonies on Congo red agar failed to develop black crystalline consistency in the presence of curcumin.

Microsoft excel datasheet was used for tabulation and analysis of the data by calculation of percentage and the simple ratios.

\section{Results and Discussion}

A total of 400bacterial pathogens from various samples were screened for biofilm production by Congo red agar method and60 biofilm producing bacterial strains were identified. This includes 15 gram positive $(S$. aureus and $E$. faecalis) and 45 gram negative bacteria (E. coli, K. pneumoniae, $C$. freundii and $P$. aeruginosa). The bacterial 
strains recovered from various sample and their percentage is shown in Table 1. The biofilm producer bacteria were mainly urinary $(n=32,53.3 \%)$ and pus isolates $(\mathrm{n}=22, \quad 36.6 \%)$. Sputum, aspirate and endotracheal secretion recovered only 3,2 and 1 biofilm producing strain respectively.

The minimum biofilm inhibitory concentrations (MBIC) of curcumin were determined in these isolates and are shown in Table 2. All isolates showed inhibition of biofilm formation at $128 \mu \mathrm{g} / \mathrm{ml}$ concentration of curcumin.

Medical implications of biofilm are increasingly recognized with the development of diagnostic techniques in recent years. This complex microbial organization is found to be the preferred mode of growth on living as well as nonliving surfaces, rather than simple accumulation of microbial cells. Biofilm producing organisms are associated with native tissue / organ infections or indwelling device infections (Hall-Stoodley et al., 2004). Central and peripheral venous catheters, urinary catheters, prosthetic heart valves and intrauterine devices are the common indwelling devices from which biofilm producers can be isolated. The native host tissue infections include periodontitis, native valve endocarditis, cystic fibrosis, chronic rhinosinusitis, otitis media, chronic prostatitis, urinary tract infections and wound infections. Several studies have evaluated the prevalence of biofilm-associated infections in various clinical setups. Around $60 \%$ of biofilm producing organism have been reported from catheter associated urinary tract infections and chronic wound infections (Niveditha et al., 2012, James et al., 2008)In our study, $15 \%$ (60 out of 400) of bacterial isolates were found to produce biofilm. Majority of the biofilm producing isolates were isolated from urine samples $(n=32$, $53.3 \%)$, followed by pus $(n=22,36.6 \%)$, sputum $(n=3,5 \%)$, aspirate $(n=2,3.3 \%)$ and endotracheal secretion $(n=1,1.6 \%)$. We found the biofilm associated urinary infections were mostly among patients with indwelling urinary catheter $(n=17)$. Although biofilm production is not uncommon in commensal species found in healthy hosts, formation of biofilm by pathogenic bacteria has more medical significance. Biofilmassociated infections caused by the grampositive bacterial pathogens, such as $S$. aureus and Enterococcus sp and gramnegative bacilli, such as $E$. coli, $K$. pneumoniae and $P$. aeruginosa have been well documented. In a study conducted in USA, 91\% S. aureus, $83 \%$ P. aeruginosa, $76 \%$ K. pneumoniae, $55 \%$ Acinetobacter baumannii and $13 \%$ of E. coli isolates were biofilm producers (Sanchez et al., 2013). However, there were no significant differences in biofilm formation between the MRSA and MSSA strains. Similar results have been reported in other studies (Gjodsbol et al., 2006, Bjarnsholt 2013 )In our study, out of 60 biofilm producing isolates, majority were E. coli $(\mathrm{n}=23)$, followed by $K$. pneumoniae $(\mathrm{n}=13), S$. aureus $(\mathrm{n}=13), \quad C$. freundii $(\mathrm{n}=6), \quad P$. aeruginosa $(\mathrm{n}=3)$ and E. faecalis $(\mathrm{n}=2) .19$ of $23 \mathrm{E}$. coli isolates were associated with urinary infections.

From medical point of view, biofilm associated infections are persistent in nature and are less amenable to antimicrobial therapy. Biofilm producing bacteria display several fold increase in resistance against multiple antibiotics. The biofilm exopolysaccharide matrix imparts protection from antimicrobial molecules as well as from host immune defense. However, the mechanisms of antimicrobial resistance in biofilm is quite unique in comparison to its planktonic counterpart. In contrast to the 
intrinsic mechanisms found in planktonic cells such as altered targets, decreased antibiotic influx, enhanced efflux and enzymatic degradation, biofilms negate the antibiotic effect by decelerating the antibiotic diffusion through its matrix as the antibiotic molecules bind to the oppositely charged biofilm polymers. In addition, supporting the growth of a subpopulations of persister cells, repression of growth in response to starvation-induced stress and glucan mediated antibiotic sequestration have also been implicated in biofilmspecific antimicrobial resistance (Stewart, 2015). Furthermore, the minimum biofilm inhibitory concentration (MBIC) may exceed the toxic concentration and limit the therapeutic use of antibiotic. Consequently, therapeutic strategies to negate biofilm came up as a new area of interest in infection control (Abedon, 2015). Among the several newly proposed therapeutics, bioactive natural products have shown promising results. Curcumin is the major active phytochemical present in the rhizome of Curcuma longa, commonly known as turmeric. It is well known for its medicinal values in traditional Indian and Chinese medicine. The anti-biofilm effect of curcumin has been studied both in vivo and in vitro against various bacteria. Curcumin has displayed MIC values of $16 \mu \mathrm{g} / \mathrm{mL}$ and $128 \mu \mathrm{g} / \mathrm{mL}$ against Bacillus subtilis and $S$. aureus respectively (Ungphaiboon et al., 2005). It was also found to destabilize biofilm formation byHelicobacter pyloriat a concentration of $10 \mu \mathrm{g} / \mathrm{ml}$ (Hegarty et al., 1999). In our study, we evaluated the MBIC of curcumin against various clinical isolatesin vitro. While 18 isolates $(30 \%)$ had MBIC of $128 \mu \mathrm{g} / \mathrm{ml}$, a total of $8,19,12,2$ and 1 isolate displayed MBIC of $64 \mu \mathrm{g} / \mathrm{ml}$, $32 \mu \mathrm{g} / \mathrm{ml}, 16 \mu \mathrm{g} / \mathrm{ml}, 8 \mu \mathrm{g} / \mathrm{ml}$ and $4 \mu \mathrm{g} / \mathrm{ml}$ respectively. Among E. coli, $79.3 \%$ of isolates had MBIC of $128 \mu \mathrm{g} / \mathrm{ml}$ and among S.aureus $84.6 \%$ of isolates had MBIC of $32 \mu \mathrm{g} / \mathrm{ml}$. We found all three $P$. aeruginosa strains isolated from pus, sputum and urine samples had MBIC of $16 \mu \mathrm{g} / \mathrm{ml}$ which was similar to another study. They reported $16 \mu \mathrm{g} / \mathrm{ml} \mathrm{MBIC}$ in $P$. aeruginosa isolates from cystic fibrosis (Karaman et al., 2013). Common anti-pseudomonas antibiotics such as imipenem and aminoglycosides often found to stimulate alginate production leading to increased biofilm volume in $P$. aeruginosa at their sub-MIC concentrations which may limit their therapeutic benefits.

Table.1 Sample-wise distribution of biofilm producing bacterial isolates

\begin{tabular}{|l|c|c|c|c|c|}
\hline \multicolumn{1}{|c|}{ Organism } & Urine & Pus & Sputum & Aspirate & $\begin{array}{c}\text { Endotracheal } \\
\text { secretion }\end{array}$ \\
\hline $\begin{array}{l}\text { E. coli } \\
(\mathrm{n}=23,38.3 \%)\end{array}$ & 19 & 4 & - & - & - \\
\hline $\begin{array}{l}\text { K.pneumoniae } \\
(\mathrm{n}=13,21.6 \%)\end{array}$ & 7 & 4 & 1 & - & 1 \\
\hline $\begin{array}{l}\text { S. aureus } \\
(\mathrm{n}=13,21.6 \%)\end{array}$ & - & 11 & - & 2 & - \\
\hline $\begin{array}{l}\text { C. freundii } \\
(\mathrm{n}=6,10 \%)\end{array}$ & 4 & 1 & 1 & - & - \\
\hline $\begin{array}{l}\text { P. aeruginosa } \\
(\mathrm{n}=3,5 \%)\end{array}$ & 1 & 1 & 1 & - & - \\
\hline $\begin{array}{l}\text { E. faecalis } \\
(\mathrm{n}=2,3.3 \%)\end{array}$ & 1 & 1 & - & - & - \\
\hline
\end{tabular}


Table.2 Minimum biofilm inhibitory concentration of curcumin in biofilm producing bacteria

\begin{tabular}{|l|c|c|c|c|c|c|}
\hline & $4 \mu \mathrm{g} / \mathrm{ml}$ & $8 \mu \mathrm{g} / \mathrm{ml}$ & $16 \mu \mathrm{g} / \mathrm{ml}$ & $32 \mu \mathrm{g} / \mathrm{ml}$ & $64 \mu \mathrm{g} / \mathrm{ml}$ & $128 \mu \mathrm{g} / \mathrm{ml}$ \\
\hline E. coli $(n=23)$ & 1 & 1 & 1 & 2 & 1 & 17 \\
\hline K. pneumoniae $(n=13)$ & - & 1 & 4 & 5 & 3 & - \\
\hline S. aureus $n=13)$ & - & - & 1 & 11 & 1 & - \\
\hline C. freundii $(n=6)$ & - & - & 3 & 1 & 2 & - \\
\hline P. aeruginosa $(n=3)$ & - & - & 3 & - & - & - \\
\hline E. faecalis $(n=2)$ & - & - & - & - & 1 & 1 \\
\hline Total $(\mathrm{n}=60)$ & $1(1.6 \%)$ & $2(3.3 \%)$ & $12(20 \%)$ & $19(31.6 \%)$ & $8(13.3 \%)$ & $18(30 \%)$ \\
\hline
\end{tabular}

In contrast, exposure to the sub-MIC concentrations curcumin was not associated with increased biofilm production (Karaman et al., 2013).

The limitation of our study is less number of samples tested. We have used Congo red agar method for biofilm detection, whereas other methods like tube adherence test, micro titer plate method, scanning-electron microscopy were not used for confirmation. The low prevalence of biofilm producing bacteria in our study may be attributed to the less sample size, difference in method of biofilm detection, sample types and sites of infection, regional variation of strain types and infection control practices.

In conclusion, curcumin is a potent bioactive substance. In addition to its antimicrobial action, it has anti-biofilm effect. In our study, it was found to inhibit biofilm formation in gram positive as well asgram negative clinical bacterial isolates. Biofilm formation of all pathogenic bacterial isolates were inhibited at $128 \mu \mathrm{g} / \mathrm{ml}$ concentration of curcumin. Hence, it may have promising role in treatment of infections with biofilm forming microorganism as an adjunct to antibiotic therapy, especially in case of multidrug resistant organisms where the therapeutic options are limited to only a few antibiotics.

\section{References}

Abedon, S.T. 2015. Ecology of Anti-Biofilm Agents I: Antibiotics versus Bacteriophages. Pharmaceuticals, (Basel). 8: 525-58.

Ammon, H.P., Wahl, MA. 1991. Pharmacology of Curcuma longa. Planta Med., 57: 1-7.

Bjarnsholt, T. 2013. The role of bacterial biofilms in chronic infections. APMIS: acta pathologica, microbiologica, et immunologica Scandinavica, 121: 1-58.

Donlan, R.M., Costerton, J.W. 2002. Biofilms: survival mechanisms of clinically relevant microorganisms. Clin. Microbiol. Rev., 15: 167-93.

Freeman, D.J., Falkiner, F.R., Keane, C.T. 1989. New method for detecting slime production by coagulase negative staphylococci. J. Clin. Pathol., 42: 872-4.

Gjodsbol, K., Christensen, J.J., Karlsmark, T., Jorgensen, B., Klein, B.M., Krogfelt, K.A. 2006. Multiple bacterial species reside in chronic wounds: a longitudinal study. Int. Wound J., 3: 225-31.

Hall-Stoodley, L., Costerton, J.W., Stoodley, P. 2004. Bacterial biofilms: from the natural environment to infectious diseases. Nature reviews Microbiol., 2: 95-108. 
Hayakawa, H., Minaniya, Y., Ito, K., Yamamoto, Y., Fukuda, T. 2011. Difference of curcumin content in Curcuma longa L.(Zingiberaceae) caused by hybridization with other Curcuma species. American J. Plant Sci., 2: 111.

Hegarty, J.P., Dowd, M.T., Baker, K.H. 1999. Occurrence of Helicobacter pylori in surface water in the United States. J. Appl. Microbiol., 87: 697701.

James, G.A., Swogger, E., Wolcott, R., Pulcini, E., Secor, P., Sestrich, J., Costerton, J.W., Stewart, P.S. 2008. Biofilms in chronic wounds. Wound repair and regeneration : official publication of the Wound Healing Society [and] the European Tissue Repair Society.16: 37-44.

Kali, A., Bhuvaneshwar, D., Charles, P.M.V., Seetha, K.S. 2016. Antibacterial synergy of curcumin with antibiotics against biofilm producing clinical bacterial isolates. $J$. Basic and Clin. Pharmacy, 7(3): 9396.

Karaman, M., Firinci, F., Arikan Ayyildiz, Z., Bahar, I.H. 2013. Effects of Imipenem, Tobramycin and Curcumin on Biofilm Formation of Pseudomonas aeruginosa Strains. Mikrobiyoloji bulteni, 47:192-4.

Negi, N., Prakash, P., Gupta, M.L., Mohapatra, T.M. 2014. Possible Role of Curcumin as an Efflux Pump Inhibitor in Multi Drug Resistant Clinical Isolates of Pseudomonas aeruginosa. J. Clin. Diag. Res., JCDR.
8: DC04-7.

Niveditha, S., Pramodhini, S., Umadevi, S., Kumar, S., Stephen, S. 2012. The Isolation and the Biofilm Formation of Uropathogens in the Patients with Catheter Associated Urinary Tract Infections (UTIs). J. Clin. Diag. Res., $h$ JCDR, 6: 1478-82.

Percival, S.L., Vuotto, C., Donelli, G., Lipsky, B.A. 2015. Biofilms and Wounds: An Identification Algorithm and Potential Treatment Options. Adv. wound care, 4: 389-97.

Reiter, K.C., T.G. Dasp, C.F. Deo, D'Azevedo, P.A. 2011. High biofilm production by invasive multiresistant staphylococci. APMIS : acta pathologica, microbiologica, et immunologica Scandinavica., 119: 776-81.

Sanchez, C.J., Jr., Mende, K., Beckius, M.L., Akers, K.S., Romano, D.R., Wenke, J.C., Murray, C.K. 2013. Biofilm formation by clinical isolates and the implications in chronic infections. BMC Infectious Dis., 13: 47.

Stewart, P.S. 2015. Antimicrobial Tolerance in Biofilms. Microbiology spectrum, 3: 10 .

Ungphaiboon, S., Supavita, T., Singchangchai, P., Sungkarak, S., Rattanasuwan, P., Itharat, A. 2005. Study on antioxidant and antimicrobial activities of turmeric clear liquid soap for wound treatment of HIV patients. Songklanakarin J. Sci. Technol., 27: 269-578.

\section{How to cite this article:}

Pravin Charles, M.V., Arunava Kali, Bhuvaneshwar and K.S. Seetha. 2016. Inhibitory Effect of Curcumin on Biofilm Produced by Bacterial Pathogens. Int.J.Curr.Microbiol.App.Sci. 5(12): 692-697. doi: http://dx.doi.org/10.20546/ijcmas.2016.512.078 